\title{
Grafting as an Alternate Tool for Biotic and Abiotic Tolerance with Improved Growth and Production of Solanaceous Vegetables: Challenges and Scopes in India
}

\author{
Aradhana Sen*, Ranjit Chatterjee, Pranali Bhaisare and Sushmita Subba
}

Department of Vegetable and Spice crops, Uttar Banga Krishi Viswavidyalaya, Pundibari, Coochbehar, West Bengal, India

*Corresponding author

\begin{tabular}{|c|}
\hline Keywords \\
\hline $\begin{array}{l}\text { Grafting, Organic } \\
\text { farming, Biotic and } \\
\text { abiotic stress } \\
\text { tolerance }\end{array}$ \\
\hline Article Info \\
\hline $\begin{array}{l}\text { Accepted: } \\
04 \text { December } 2017 \\
\text { Available Online: } \\
\text { 10 January } 2018\end{array}$ \\
\hline
\end{tabular}

\section{Introduction}

A healthy and surplus yield from the land with minimum input is a dream that every farmer aspires for. Since time unknown humans' have tried and is still trying to discover diverse techniques and process to improve crop production and to increase the profit from the land. Sometimes in order to gain more profit the farmer often become negligent and knowingly or unknowingly he use the chemicals which may have detrimental effects not only on the consumer health but also on the farmer himself and may also cost his life while dealing with it, current example is the death of around 11 and hospitalization of 472 
farmers in Yavatmal of Maharashtra while spraying pesticides in cotton field (Anon, 2017). The area under suitable cultivation of vegetables is 9541000 ha it is mostly restricted and remains more or less constant year after year, in which the vegetables of solanaceous family holds a large share(Anon, 2015b). Vegetables shares major part of the daily dishes prepared in Indian kitchen and are rich in carbohydrate, vitamins, minerals and other phyto-nutreucical. But less do we know that these vegetables are heavily-laden with pesticides. According to a survey report status of pesticide residues in India (April, 2014 March, 2015) samples of capsicum, green chilli and cauliflower were found having high number of above MRL residues followed by samples of cabbage, eggplant, tomato, okra, bitter gourd, cucumber, green pea and coriander leaves (Anon, 2015a).

Farmers often use perilous chemicals to overcome the loss due to disease and pests. Though Various other environment friendly methods like using resistant varieties or cultivars produced by conventional method of breeding or by using biotechnological tools are also available but they are too much time consuming and require a huge input on research and trials on and off field. In many cases it has been found that even after showing successful stress resistance the genetically engineered crop plants are struggling to create their acceptability in many countries because to fear of various misconceived ideas. Crop rotation can restrict the spread of soil borne pathogens but the area under vegetable cultivation is restricted and remains in use throughout the year moreover overwintering of the infected land causes increase in number too due to growth of other hosts and it do not guarantee the total pathogen free soil as these pathogens may survive in the soil in dormant condition for years (Garber, 1973). Steaming of soil is highly effective but extremely costly and requires high cost equipments. In this situation it is needed that other techniques are to be explored and grafting can be one of them as it is quick, practical in its application and ecofriendly.

Grafting though sounds unique and new to many but it is claimed that hints of its practice have been found in ancient Biblical text. The term grafting means transplanting of living tissue. In terms of plant science it means the techniques of uniting two different plants or plant parts in such a way that their vascular system will joined and they will grow together as a single plant exhibiting the characters of both separately. The upper part of the union which bears flower or fruit called the scion and the lower part which holds on the ground is called rootstock. The part used as a scion can be the entire twig or a single bud. It has been practiced from many years in Eastern Asia to overcome various vegetable production issues associated with intensive cultivation using limited arable land.

Its mention has also been found in ancient book written in China in the 5th century and in Korea in the 17th century (Lee and Oda 2003). Initially only the woody perennials were mainly subjected to grafting and by the starting of 20th century grafting began to be used extensively for propagation of annual vegetable crops too (Louws et al., 2010). It is highly popular in Greece, especially in southern areas (Traka-Mavrona et al., 2000). The first interspecific, herbaceous grafting was recorded in 1920 for watermelon (Citrullus lanatus), in Japan (Tateishi, 1927; Sato and Takamatsu 1930) but for Solanaceous vegetables it took 30 more years (1960's) to commercialise grafting in their production (Lee and Oda, 2003) and the first record of eggplant (Solanum melongena L.) grafted on scarlet eggplant (Solanum integrifolium Poir.) was reported in the 1950s (Oda, 1999). 
Awareness of the chemical residues and their effects on health and legitimate phase out of various pesticides have reawakened the consumers and had made them realise the importance of naturally grown products because of this in recent years, the organically grown vegetables has shown a steep increase in their market demand. Observing the present scenario is quite obvious to predict that future of organic market is going to get more promising. The growers need to be prepared to grab this opportunity and find alternatives which will be not only cost effective, made available in short time in a large number to the growers but also will not need any inorganic inputs on field after planting and the grafted seedlings can be a very reliable approach fulfilling all these criteria, the grafted plants are not only resistant to production problems like vigour, soil pests and diseases under various stressed environmental condition but also to low or high temperature, salinity, water logging, drought, heavy metals and organic pollutants again it can enhance the uptake of nutrients and water use efficiency, increase superior quality of yield by restricting various anti nutritional factors and give more return by expanding the yielding time. Grafting is also reported to increase the of endogenous hormones synthesis in plants (Proebsting et al., 1992); improves water use efficiency which can help to grow plants where regular irrigation is difficult to practice on time; to increase flower and seed production even in stressed environmental conditions (Cohen and Naor, 2002; Lardizabal and Thompson, 1990)

\section{Influence of grafting on biotic stress tolerance}

\section{Disease tolerance}

Soil borne diseases like Fusarium (Fusarium oxysporum $f$. sp. lycopersici, race 1 and race 2) and verticillium wilts (Verticillium dahliae, races 1 and races 2), bacterial speck
(Pseudomonas syringae p.v. tomato), root knot nematodes (Melodogyne spp.) and corky root (Pyrenocheata lycopersici) have been reported to be among the most destructive for protected tomato crops (Besri, 2002; Poffley, 2003). These used to be controlled by fumigants from which methyl bromide but after the Copenhagen Amendment to the Montreal Protocol in 1992, most of the countries around the globe phases out methyl bromide by 1 January 2005 as it was added to the list of substances that deplete the ozone layer (Anon, 2014).

With rapid development in intensive protected cultivation grafting has become a crucial tool. Root stocks of certain species have excellent tolerance to various soil-borne diseases like Fusarium, Verticillium, Phytophthora, nematodes, and other pests, this kind of resistance developed in the grafted plants may be resulted from limited colonization of bacteria or pathogen in the lower stem and preventing them from invading xylem tissues (Grimault and Prior, 1994). One more reason could be the inherent resistance of the rootstocks and improved plant nutrient uptake which improves disease control in grafted vegetable plants (Table 1).

Few experiments have also reported to provide some protection from viruses when the susceptible scions were grafted on specific root socks. Mahmoud, (2014) found that grafting increased TYLCV tolerance in susceptible plants, delayed the appearance of TYLCV symptoms and increase of yield components compared to non-grafted plants in tomato. Iouannou (2001) observed grafted eggplants showed lower disease incidences with higher yield and fruit size. Similar type of observations were obtained when tomato was grafted onto Beaufort' rootstocks ( $S$. lycopersicum and $S$. habrochaites (Hasna et al., 2009). Tomatoes (Solanum lycopersicum L.) when grafted onto commercial rootstock 
and subjected to infection with Verticillium dahliae, the grafted plant exhibited resistance to the verticillium wilt disease (Paplomatas et al., 2002). Grafting of chilli peppers (Capsicum annuum L.) is a recent practice where $C$. annuum scions are grafted onto $C$. annuum rootstocks that have soilborne disease and nematode resistance (Morra and Biloto 2006).

Rivard and Louws (2008) found that 'German Johnson' heirloom tomatoes had $0 \%$ fusarium wilt incidence in infested soils when grafted onto resistant CRA 66 or Hawaii 7996 tomato rootstock, compared to a $79 \%$ incidence on non-grafted controls.

\section{Nematode tolerance}

Grafting can be a promising alternative to soil fumigants and a great tool in integrated pest management practice in various crop production systems (Kubota et al., 2008). Grafting of tomato on Beaufort significantly reduced root galling due to root-knot nematodes (Kaskavalci et al., 2009).

Charles et al., (2012) in Florida conducted an experiment and opined that when hybrid rootstocks used for grafting of tomato it significantly reduced root galling due to root knot nematode compared with the non-grafted and self-grafted scions by ' $80.8 \%$ in organic field and by $97.1 \%$ in transitional field' when grafted on Survivor rootstock. Similar results were obtained by Burelle et al., (2016). Where he observed non grafted Florida 47 showed more root galling than the grafted plants when 'TX301', 'Multifort', and 'Aloha' used as root stock. Using jimson weed (Datura stramonium L.) as a rootstock for grafting tomato, eggplant and sweet pepper showed resistance to root knot nematode infection which results in poor absorption of water and nutrients (Lowman and Kelly 1946).

\section{Insect tolerance}

Cortez-Madrigal (2012) reported that grafted tomatoes were less prone to tomato psyllid than the non-grafted, the preference of adult psyllids was 22.8 times higher in tomato than tinguaraque, and three times higher than for grafts. He also studied incidence of other pests and found presence of miners and aphids graft showed an intermediate (2.18 \pm 2.16$)$.

\section{Influence of grafting on abiotic stress tolerance}

Environmental stress is the most important limiting factor in the current climatic situation for plant growth and horticultural productivity worldwide. Extreme temperature, draught and salinity are the major ones which have influenced crop productivity the most (Schwarz et al., 2010). Increasing global warming, expansion of the saline affected area and lack of availability quality water storage in arid lands are becoming a limiting factor for crop production and climatologists believe that the combined environmental stress in the tropics will only get worse over time. Though several stress tolerant cultivars have been produced through breeding but the complex nature of the genetic tolerance of environmental factors makes it difficult and time consuming (Ashraf and Foolad, 2007) and grafting can be a rapid alternative to develop environmental stress tolerant planting material (Table 2).

\section{Temperature tolerance}

Low temperature tolerance: Various research studies have shown that, grafting can remarkably enhance extreme temperature tolerance in plants. low temperature stress were remarkably enhanced in tomatoes when it was grafted unto high altitude rootstock 'LA 1777 ' of $S$. habrochaites, 'KNVF' (the interspecific hybrid between $S$. lycopersicum $x$ 
S. habrochaites) and a back cross hybrid rootstocks between $S$. habrochaites 'LA 1778 , x S. lycopersicum cv. T5 (Okimura et al., 1986; Bloom et al., 2004; Venema et al., 2008). As these rootstocks are related to the eggplants it is possible that they can be used to improve vegetative growth and yield of eggplants at very low temperature (Gao and Liao, 2006). Torvum vigour' an accession of Solanum torvum can also be used as rootstock for both tomato and eggplant to impart low temperature tolerance (Okimura et al., 1986).

High temperature tolerance: Several researches have demonstrated that different tomato rootstocks have high temperature tolerance and have the ability to transfer tolerance to scions when appropriately grafted (Bloom et al., 2004; Venema et al., 2008; Zijlstra and Nijs, 1987). Wild species of tomato have wider temperature thresholds than the domesticated lines and can be used as root stocks (Venema et al., 2005). The grafted plants exhibited greater quantity of flowers, trusses and fruit production in when compared to non-grafted controls at temperatures considered non-optimal for the scion. However, using eggplant rootstock may be more promising for higher temperature.

Wang et al., (2007) observed yield increases of $10 \%$ on eggplant when grafted onto heattolerant eggplant rootstock, as they are better adapted to high temperature and arid climate (Abdelmageed and Gruda, 2009). Apart from this various other heat-tolerant rootstocks offers a certain degree of resistance against thermal stress in tomato (Rivero et al., 2003b). Chilli pepper rootstocks (C. chacoense, $C$. baccatum, $C$. frutescence, and $C$. annum) also improved performance of the scions and confirmed high yields under high-temperature environments (Palada and $\mathrm{Wu}, 2008$ ). Similarly when eggplants scion ( $S$. melongena cv. Yuanqie) grafted onto heat-tolerant rootstock ( $S$. melongena $\mathrm{cv}$. Nianmaoquie) performed very well, giving a significant increase in growth and yield by $10 \%$ (Wang et al., 2007).

\section{Drought tolerance}

Day by day moisture stress is becoming an increasingly important issue in agriculture throughout the world especially in arid and semiarid regions (Schwarz, 2010). One of the most common problem with the arid climate is unprotected water resource and grafting can be a rapid and proactive way to cope up with such kind of situation and increase water use efficiency (Garcia-Sanchez et al., 2007; Satisha et al., 2007). Most of the eggplants are drought tolerant hence grafting unto wild eggplants and interspecific hybrids can improve yield and fruit quality under drought conditions Petran, (2013). In an experiment it was observed that grafting cherry tomatoes unto drought resistant rootstocks significantly enhanced fruit quality and yield (SanchezRodriguez et al., 2012).

\section{Flood tolerance}

Though water is important for the plants but excess of water results in oxygen deficiency in the root zone and may cause hindrance in root respiration which lead to rotting and disease attack. These obstacles caused by excess of water availability or flooding can be fixed by grafting onto tolerant plant. Petran, (2013) found that, grafting tomato on $S$. torvum rootstocks improved the flood tolerance and yield significantly. Symptoms associated with flood stress like depression in photosynthetic rate, stomatal conductance, transpiration and soluble proteins has been proved to be lessened when crops are grafted onto floodtolerant rootstock which improves water use efficiency in drought conditions and flood resistance of crops by grafting onto tolerant rootstocks is an appealing low-input option (Kato et al., 2001). 


\section{Salinity tolerance}

Due to application of excess and injudicious application of chemical fertilizers about one third of the land of the globe has now became saline (Rivero et al., 2003a) excess salinity, either of the soil or of the applied irrigation water is one of significant environment factors that enormously impacts the crop growth and productivity (Santa-Cruz et al., 2002) as it impacts the physiology, biochemistry and yield of plants, grafting can be a great rescue in significantly decreasing the yield loss due to salinity and salt-tolerant rootstock may possibly become a key management tool for vegetable production under saline conditions in anticipation of better land-use systems that can significantly reduce the extent of crop loss in areas where salinity is intolerable (Rivero $e t$ al., 2004). According to the study of Fernandez-Garcia et al., (2004b) when the salinity resistant rootstocks 'Radja', 'Pera' and hybrid 'Volgogradskij' $\mathrm{x}$ 'Pera' were used as rootstocks at high levels of sodium chloride, the yield was significantly increased by $80 \%$ more than the non-grafted plants, again the amount of sodium and chlorine in the leaves of the grafted plants were also less as the rootstock must have barred the delivery of these harmful ions into the scion.

\section{Harmful pollutants}

The increasing levels of heavy metals in agricultural land are gradually becoming an serious threat not only for crop plants, but also for the environment and human health (An et al., 2004; Gratão et al., 2005; Clemens, 2006; Hong-Bo et al., 2010; Raskin et al., 1997). Non judicial use of large amounts of chemicals, irrigation with the reclaimed wastewater, the application of contaminated soil amendments, sewage sludge and other anthropogenic activities have dramatically increased the concentrations of several nutrient ions as well as heavy metals in the soils (Guo et al., 2004; He et al., 2005; Yu et al., 2005). Several promising research reported that grafting vegetables can be a way to overcome this problem. Grafting alter ability of plant to filter uptake of potentially harmful organic pollutants (Otani and Seike, 2007). Arao et al., (2008) reported reduction in cadmium $(\mathrm{Cd})$ concentrations in eggplant fruit by grafting Solanum melongena onto Solanum torvum, they observed that the grafting resulted in reduced leaf and stem $\mathrm{Cd}$ concentrations by $67-73 \%$ in comparison to non-grafting.

\section{Enhancement in plant growth with better yield and quality}

In an experiment conducted by Khah (2005) it was reported that grafted plants have higher plant height, leaf area index, as well as the fresh and dry weights of stems and leaves and yield was comparatively higher than the nongrafted plants. Harvesting of fruits was also 7 days earlier for the grafted tomato plants. Similar observation was also recorded by Gisbert et al., 2011 and Rahman et al., 2002 when they grafted eggplant cultivars onto perennial and wild Solanaceous species. Augmented water and nutrient uptake improved stomatal conductance in tomato when grafted onto vigorous rootstock (Fernandez- Garcia et al., 2004a). Improved photosynthesis rates of grafted plants increase the crop productivity (Matsuzoe et al., 1993). According to Besri, (2003) 15-20\% of yield increase was reported for the grafted tomatoes even when only half of the plants were planted. Grafting resulted in bigger fruit size in tomatoes, and thus increased the yield (Pogonyi et al., 2005).

Khah (2005) reported that the grafted eggplants plants had lesser number of seeds than the non-grafted plants fruit. Grafting also affects shape, skin colour, skin or smoothness of rind, texture of fruit flesh, soluble solids 
concentration, firmness and improves postharvest life of the fruits in pepper, tomato and eggplants as affirmed by Nkansah et al., (2013) and Cheng et al., (2012).

According to Gisbert et al., (2011) experiment the fruit protein content, total fruit phenolics content of grafted eggplant plants was higher in comparison to that from non-grafted. Studies revealed that vitamin $\mathrm{C}, \beta$-carotene content and the antioxidant capacity of tomatoes and bell pepper showed significant increase when grafted (Chávez-Mendoza et al., 2013 and Fernandez-Garcia et al., 2004b). Tsouvaltzis et al., (2004) found that when the tomato cultivar, 'Sacos' was grafted onto 'Primavera' rootstock concentration of calcium in tomato was comparatively higher than the fruits from non-grafted tomato plants. Similar results were confirmed by Khah et al., (2006) when they grafted tomato onto 'HeMan' rootstock.

\section{Grafting as alternate source of livelihood for rural vegetable growers}

The demand of grafted seedling is increasing within the country and in global market. The proportion of the area covering under grafted plants of watermelon, cucumber, melon, tomato and eggplant rose to $57 \%$ in 1980 , and to $59 \%$ in 1990 in Japan (Oda, 1993) and it is increasing day by day. Soil fumigants become increasingly expensive and regulated, which resulted in growing interest in grafting, and researchers are now striving to increase grafting efficiency and minimize labor costs (Rivard et al., 2010). It can be said with recent development soon it will get popularized in India too, to meet this growing demand the vegetable grower in general and rural youth in particular can be trained for large scale production of grafted seedlings.

Considering the negative impact of climate change grafted seedlings can be promoted for mass cultivation in drought and salinity affected areas where most of the land remains unused as waste lands and under the changing climate, this technique could play significant role to improve vegetable productivity in these areas.

Through adaptation of grafted seedling cultivation farmer can save the cultivation cost spent on different pesticides which will also minimize effect of pesticide on human, livestock and environment health.

As a result of the improved growth and vigour from grafting with interspecific and hybrid rootstocks in tomato, many growers have gotten rid of decreased planting densities (Besri, 2003). Thus planting less plants will give more yield from the land.

Continuous cropping is inevitable in vegetable production in indoor areas, which gradually decreasing the yield and quality of produce. Soil sterilization can never be an immune as some amount of pathogens are always be found and causes multiplication during crop growth.

In such situation grafting can become an essential technique for the continuous cropping of fruit-bearing vegetables grown in greenhouses.

\section{Challenges in grafting}

Small amounts of alkaloids to the fruits from the rootstock may occur as observed when tomatoes were grafted onto jimson weed (Lowman and Kelly, 1946). The improved resistance and better yield with grafted plants was inconsistent in some cases.

Proper knowledge rootstock-scion compatibility is required which may not be available and understood properly by the rural farmers. 
Table.1 Potential rootstocks of solanaceous vegetable for biotic stress tolerance

\begin{tabular}{|c|c|c|}
\hline Crop & Biotic stress & Potential root stocks \\
\hline \multirow[t]{6}{*}{ Tomato } & Fusarium wilts & Efialto \\
\hline & Bacterial wilt & $\begin{array}{l}\text { Dai Honmei, RST-04-105-T, VI046103 } \\
\text { (EG195), VI045276 (EG203), Shin } \\
\text { cheong gang F1, and Nordox }\end{array}$ \\
\hline & Fusarium crown and root rot & Natalia, Cuore di Bue F1 and He-Man F1 \\
\hline & Southern blight & Beaufort, and Maxifort \\
\hline & Verticillium wilt & Beaufort \\
\hline & Root knot nematode & $\begin{array}{l}\text { Big Power, VI046103 (EG195) and } \\
\text { VI045276 (EG203) }\end{array}$ \\
\hline \multirow[t]{2}{*}{ Pepper } & Phytophthora blight & PR 920', 'PR 921', and 'PR 922 \\
\hline & Corky root & Eldorado, Beaufort, Snooker \\
\hline \multirow[t]{2}{*}{ Brinjal } & Bacterial Wilt & $\begin{array}{l}\text { Solanum toxicarium, S. torvum and } S \text {. } \\
\text { integrifolium }\end{array}$ \\
\hline & Nematode & Beaufort \\
\hline
\end{tabular}

Source: Bolandnazar et al., 2014; Rivard et al., 2012; Keatinge et al., 2014; Onduso, 2014; Vitale et al., 2014; Hibar et al., 2006; Kaskavalci et al., 2009; Mochizuki and Yamakawa, 1979; Jang et al., 2012; Al- Chaabi et al., 2009; Rivard et al., 2010.

Table.2 Potential rootstocks of solanaceous vegetable for abiotic stress tolerance

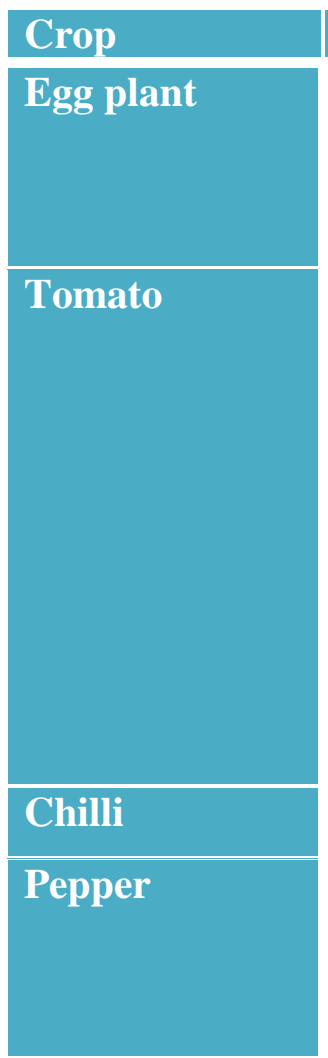

\section{Abiotic stress}

High temperature tolerance

Tolerant to drought

Higher yield even at low temperature

Resistant to water-logging

Low and high temperature tolerance

Resistant to drought

Tolerant to drought

Tolerance to cold and chilling

Tolerant to humidity

Resistant to salt

Tolerance to salt

Flood- and drought-tolerances

High temperature tolerant

Flooding tolerance

Water stress tolerent
Potential root stocks

Solanum integrifolium $\times$ Solanum melongena

Solanum macrocarpum, Solanum gilo, PKM-1

S. integrifolium $x$ S. melongena

Solanum laciniatum

Solanum melongena

Solanum chilense

Solanum pennelli

Solanum habrochaites

Solanum cerasiforme

Solanum cheesmanii

Solanum galapagense

Solanum torvum, 'EG195' or 'EG203, 'PP0237-7502, PP0242-62

C. аппиитсv.Toom-1 and 9852-54(AVRDC)

Chili accessions 'PP0237-7502', 'PP0242-62' and 'Lee B'

Atlante, C-40, Serrano, PI-152225, ECU-973, BOL-58 and NuMex Conquistador

Source: Lee et al., (2010); Pandey and Rai (2003); Penella et al., 2014; AVRDC 2003 \& 2009. 
The majority of users of grafted seedlings is currently greenhouse hydroponic tomato growers, whereas it is still a relatively unknown technique for open-field vegetable growers.

Successful production of grafted plants requirements including synchronization and good germination rates of the rootstock and scion, and high rates of graft success and stand establishment after transplant, which may not be possible for all cases.

Maintaining optimum temperature, humidity, light intensity during the post grafting stage is essential for successful establishment of the grafts which is very difficult in open field condition.

Handling of newly grafted seedlings is tedious as they are too delicate and are very prone to disease and pest attack.

Trained personnel are required to carry out the entire process of grafting. Especially in rural areas availability of trained personnel is a big challenge.

Grafting is a labor-intensive propagation process. More awareness is required about its benefits.

Every season the seedlings needed to be prepared or purchased which discourages large scale adoption.

Uniform production of promising rootstocks is also a big challenge for large growers.

\section{Measures to popularize grafted plants for commercial cultivation among Indian Farmers}

Information regarding resistance/tolerance of commercially available rootstocks and potential germplasm usable for breeding new rootstocks are need to be collected based on locally conducted trials and research.

Several weed species of different solanaceous vegetable can act as potential rootstock should be documented, tested and utilized.

For example, selected lines of Solanum torvum Swartz (Turkey berry emerged as a promising rootstock, which is a weed in Florida)

Utilization of biotechnological tools for developing rootstock has been also attempted by researchers in various countries and it should also be promoted in India.

For large scale cultivation of grafted vegetable seedling and the cost of grafting, must be reduced, for example by the introduction of robots for mass production.

Arrangement of awareness and training programme for farmers by the state government and state agriculture universities time to time with new updates regarding grafting techniques will help to motivate the farmers.

Providing initial subsidies to the farmers from the government for shifting from non-grafted to grafted seedling cultivation and helping them to set up small production unit for producing grafted seedlings will encourage quick adoption.

Mass awareness from government as well as private sectors and NGO's regarding the need of grafted plants to combat the pesticide laden cultivation in present day under changing climate scenario is the need of hour. Although India is the second largest producer of the vegetables but the use of grafted planting material for commercial cultivation is meagre Asian Nations Japan, Korea, China used more than $50 \%$ of their vegetable crop seedling in 
the form of grafted plants. Several countries of the world are promoting grafted seedlings for different solanaceous vegetable. Considering the positive outcomes from numerous research works conducted round the globe on grafting of solanaceous crops it can be predicted that even if $25-30 \%$ area of the cultivated area of solanaceous vegetables can be converted into grafted plant cultivation a giant share money spent on chemicals like fungicide, pesticide, insecticide etc. can be saved thus farming will not only becomes environment friendly but also the amount saved can be spent by farmer to improve his livelihood.

\section{References}

Abdelmageed, A.H.A. and Gruda, N. 2009. Influence of Grafting on Growth, Development and some Physiological Parameters of Tomatoes under Controlled Heat Stress Conditions. European Journal of Horticultural Science. 74(1):16-20.

Al- Chaabi, S., Koutifani, O., Safeih, M.H. and Asmar, J. 2009. Management of Root-Knot Nematodes and Corky Root Disease of Pepper Plants by Grafting Technique onto Resistant Rootstocks under Plastic House. February 2009. https://www.researchgate.net

An, Y., Kim, Y., Kwon, T. and Jeong, S. 2004. Combined effect of copper, cadmium, and lead upon Cucumis sativus growth and bioaccumulation. Science of the Total Environment. 326: 85-93.

Anonymous 2014. Introduction: Methyl Bromide and the montreal protocol. Phasing-out Methyl Bromide in Developing Countries. Pp: 11-14.

Anonymous. 2015. Pesticide cause farmer deaths, illness in Yavatmala. National news column, Dated 5th october 2017, The Hindu. India.
Anonymous. 2015a. Monitoring of Pesticide Residues at National Level Annual Progress Report (April, 2014 - March, 2015) Department of Agriculture, Cooperation \& Farmers Welfare Ministry of Agriculture \& Farmers Welfare Krishi Bhawan, New Delhi Project Coordinating Cell All India Network Project on Pesticide Residues Indian Agricultural Research Institute New Delhi, India.

Anonymous. 2015b. Horticultural Statistics at a Glance 2015. Horticulture Statistics Division Department of Agriculture, Cooperation \& Farmers Welfare Ministry of Agriculture \& Farmers Welfare Government of India. New Delhi, India.

Arao, T., Takeda, H. and Nishihara E. 2008. Reduction of cadmium translocation from roots to Shoots in eggplant (Solanum melongena) by grafting onto Solanum torvum rootstock. Soil Science and Plant Nutrition. 54:555-559.

Arao, T., Takeda, H., Nishihara, E., 2008. Reduction of cadmium translocation from roots to shoots in eggplant (Solanum melongena) by grafting onto Solanum torvum rootstock. Soil Sci. Plant Nutr. 54, 555-559.

AVRDC 2003. Guide. Grafting tomatoes for the production in the hot-wet season. Asian Vegetable Research and Development Center, Pub. No 03-551, Shanhua, Tainan, Taiwan, 6pp.

AVRDC 2009. Guide. Grafting sweet peppers for the production in the hotwet season. Asian Vegetable Research and Development Center, Pub. No 09722, Shanhua, Tainan, Taiwan, 8pp.

Besri M., 2003. Tomato grafting as an alternative to Methyl Bromide in Morocco. Proceedings of the international research conference on methyl bromide alternatives and 
emissions reductions, November 3-6, 2003, San Diego, California, 12.

Besri, M. 2002. Tomato grafting as an alternative to methyl bromide in Morocco. Institute Agronomieque et Veterinaire Hasan II. Morocco

Bloom, A. J., Zwieniecki, M. A., Passioura, J. B., Randall, L.B., Holbrook, N.M., St. and Clair, D. A. 2004. Water relations under root chilling in a sensitive and tolerant tomato species. Plant Cell Environment. 27: 971-979.

Bloom, A., M. Zwieniecki, J. Passioura, L. Randall, N. Holbrook, and D. St Clair. 2004. Water relations under root chilling in a sensitive and tolerant tomato species. Plant, Cell and Environment. 27(8):971-979.

Bolandnazar, S., Moghbeli, E.M., Panahandeh, J. and Arzanlou, M. 2014. Biological control of fusarium wilt in greenhouse tomato by Mycorrhizal fungi and resistant rootstock. Acta Horticulturae. 1041:127-132.

Burelle, K. N., Butler, D. M., Hong, J. C., Bausher, M. G., McCollum, G. and Rosskopf, E. N. 2016. Grafting and paladin pic-21 for nematode and weed management in vegetable production. The journal of nematology. 48(4): 231240.

Charles E., Barrett, C. E. and Xin Zhao. 2012. Grafting for Root-knot Nematode Control and Yield Improvement in Organic Heirloom Tomato Production. Hort Science. 47(5):614-620.

Chávez-Mendoza, C., Sánchez, E., CarvajalMillán, E., Muñoz-Márquez, E. and Guevara-Aguilar, A. 2013. Characterization of the nutraceutical quality and antioxidant activity in bell pepper in response to grafting. Molecules. 18: 15689-15703.

Cheng Z., Wang, P., Zhou, Y., JI, Y., Liang, P., Wan, Z., Hao, J. 2012. Effects of Different Resistant Rootstocks on Yield and Quality of Grafted Tomato and Control Effects of Meloidogyne incognita. Journal of Horticulture and Landscape. 1(20): 83-87.

Clemens, S., 2006. Toxic metal accumulation, responses to exposure and mechanisms of tolerance in plants. Biochimie. 88: 1707-1719.

Cohen, S. and Naor, A. 2002. The effect of three rootstocks on water use, canopy conductance and hydraulic parameters of apple trees and predicting canopy from hydraulic conductance. Plant, Cell and Environment. 25: 17-28.

Cortez-Madrigal, H. 2012. Grafts of Crops on Wild Relatives as Base of an Integrated Pest Management: The Tomato Solanum lycopersicum as Example. Integrated Pest Management and Pest Control - Current and Future Tactics. 127-146.

Cuartero, J., Bolarin, M., Asins, C. and Moreno V. 2006. Increasing salt tolerance in the tomato. Journal of Experimental Botany. 57:1045-1058.

Fernandez-Garcia, N., Martinez, V. and Carvajal, M. 2004a.Effect of salinity on growth, mineral composition, and water relations of grafted tomato plants. Journal of Plant Nutrition and Soil Science. 167, 616-622.

Fernandez-Garcia, N., Martinez, V., Cerda, A., and Carvajal, M. 2004b. Fruit quality of grafted tomato plants grown under saline conditions. Journal of Horticultural Science and Biotechnology. 79: 995-1001.

Gao,.Q.H., Xu, X.F. and Wang, Y.W. 2006. Effect of grafting on cold tolerance in eggplant seedlings. Acta Horticulture. 771: 781-789.

Garbar 1973. Fungus penetration and development. In. Proceedings of a work conference, 30 August- 1 september 1971. Texas USA, pp-69-77. 
Garcia-Sanchez, F., Syvertsen, J.P., Gimeno, V., Botia, P. and Perez-Perez, J.G. 2007. Responses to flooding and drought stress by two citrus rootstock seedlings with different water-use efficiency. Biologia Plantarum. 130:532-542.

Gisbert, C., Prohens, J., Raigón, M.D., Stommel, J.R. and Nuez, F. 2011. Eggplant relatives as sources of variation for developing new rootstocks: Effects of grafting on eggplant yield and fruit apparent quality and composition. Scientia Horticulturae. 128(1): 14-22.

Gratão, P.L., Polle, A., Lea, P.J., Azevedo, R.A. 2005. Making the life of heavy metalstressed plants a little easier. Functional Plant Biology. 32: 481-494.

Grimault, V. and Prior, P. 1994. Grafting tomato cultivars resistant or susceptible to bacterial wilt: Analysis of resistance mechanisms. Journal of Phytopathology. 141: 330-334.

Guo, W.Z., Liu, S.F., Li, D.R., Zhao, S.S., 2004. Mechanisms of soil salinization in protected cultivation. Soils 36, 25-29 (in Chinese with English abstract)

Hasna, M.K., Ogren, E., Persson, P., Ma'rtensson, A. and Ramert, B. 2009. Management of corky root disease of tomato in participation with organic tomato growers. Crop Protection. 28: $155-161$.

He, Z.L., Yang, X.E., Stoffella, P.J., 2005. Trace elements in agroecosystems and impacts on the environment. Journal of Trace Elements

in Medicine and Biology. 19, 125-140.

Hibar, K., Daami-Remadi, M., JabnounKhiareddine, H. and Mahjoub, M. E. 2006. Control of fusarium crown and root rot of tomato, Caused by Fusarium oxysporum $\mathrm{f}$. sp. radicis-lycopersici, by Grafting onto Resistant Rootstocks. Plant Pathology Journal. 5(2): 161-165.
Hong-Bo, S., Li-Ye, C., Cheng-Jiang, R., Hua, L., Dong-Gang, G., Wei-Xiang, L., 2010. Understanding molecular mechanisms for improving phytoremediation of heavy metalcontaminated soils. Critical Reviews on Biotechnology. 30, 23-30.

Iouannou, N. 2001. Integrating soil solarization with grafting on resistant rootstocks for management of soilborne pathogens of eggplant. Journal of Horticultural Science and Biotechnology. 76: 396-401.

Jang, Y., Yang, E., Cho, M., Um, Y., Ko, K., Chun, C. 2012. Effect of grafting on growth and incidence of phytophthora blight and bacterial wilt of pepper (Capsicum annuum L.). Horticulture, Environment, and Biotechnology. 53(1): 9-19.

Kaskavalci,. Tuzel, G. Y, Dura, O. and Oztekyn, G.B. 2009. Effects of Alternative Control Methods Against Meloidogyne incognita in Organic Tomato Production. Ekoloji. 18(72): 2331.

Kato, C., Ohshima, N., Kamada, H. and Satoh, S. 2001. Enhancement of the inhibitory activity for greening in xylem sap of squash root with waterlogging. Plant Physiology and Biochemistry. 39(6): 513-519.

Keatinge, J.D.H., Lin, L.-J., Ebert, A.W., Chen, W.Y., Hughes, J.d'A., Luther, G.C., Wang, J.-F. and Ravishanka, M. 2014. Overcoming biotic and abiotic stresses in the Solanaceae through grafting: current status and future perspectives. Biological Agriculture \& Horticulture. 30(4): 272-287.

Khah, E. M. 2005. Effect of grafting on growth, performance and yield of aubergine (Solanum melongena L.) in the field and greenhouse. Journal of Food, Agriculture \& Environment. $3(3 \& 4): 92$ - 94. 
Khah, E.M., Kakava, E., Mavromatis, A., Chachalis, D. and Goulas, C. 2006. Effect of grafting on growth and yield of tomato (Lycopersicon esculentum Mill.) in greenhouse and open-field. Journal of Applied Horticulture. 8(1): 3-7.

Kubota, C., McClure, M.A., Kokalis-Burelle, N., Bausher, M.G. and Rosskopf, E.N. 2008. Vegetable grafting: History, use, and current technology status in North America. HortScience. 43:1664-1669.

Lardizabal, R.D. and Thompson, P.G., 1990. Growth regulators combined with grafting increase flower number and seed production in sweet potato. HortScience. 25: 79-81.

Lee, J.-M. and M. Oda. 2003. Grafting of herbaceous vegetable and ornamental crops. In: Janick J. (ed.). Horticultural reviews. Vol. 28. John Wiley \& Sons, New York, NY. Pp. 61-124.

Lee, Jung-Myung., Kubota, C., Tsao, S.J., Bie, Z., Echevarria, H., Morra, P.L. and Oda, M.2010. Current status of vegetable grafting: Diffusion, grafting techniques, automation. Scientia Horticulturae. 127(2,8): 93-105.

Louws, F.J., C.L. Rivard, and C. Kubota. 2010. Grafting fruiting vegetables to manage soilborne pathogens, foliar pathogens, arthropods and weeds. Scientia Horticulturae. 127:127-146.

Lowman, M.S. and J.W. Kelly. 1946. The presence of mydriatic alkaloids in tomato fruit from scions grown on Datura stramonium rootstock. Journal of American Society for Horticultural Science. 48:249-259.

Mahmoud, M.A. 2014. Grafting as a Tool to Improve TYLCV-Tolerance in Tomato. Journal of Horticultural Science \& Ornamental Plants. 6 (3): 109-115.

Matsuzoe, N., Nakamura, H., Okubo, H., and Fujieda, K. 1993. Growth and yield of tomato plants grafted on Solanum rootstocks. Journal of the Japanese Society for Horticultural Science. 61:847-855.

Mochizuki, H.; Yamakawa, K. 1979. Potential utilization of bacterial-wilt resistant Solanum species as rootstock for commercial eggplant production. Bulletin of the Vegetable and Ornamental Crops Research Station, A (Ishinden-Ogoso). 6(15):11-18

Morra, L. and Bilotto, M. 2006 Evaluation of new rootstocks for resistance to soilborne pathogens and productive behavior of pepper (Capsicum annuum L.) Journal of Horticultural Science and Biotechnology. 81:518-524.

Nkansah, G.O., Ahwereng, A.K., Amoatey, C., and Ayarna, A.W. (2013). Grafting unto African eggplant enhances growth, yield and fruit quality of tomatoes in tropical forest ecozones. Journal of applied Horticulture. 15(1): 16-20.

Oda, M. 1993. Present state of vegetable production using grafted plants in Japan. Agriculture and Horticulture. 68:442-446. (In Japanese).

Oda, M. 1999. Grafting of vegetables to improve greenhouse production. Food \& Fertilizer Technology Center Extension Bulletin: 480:1-11

Okimura, M., Matso, S., Arai, K. and Okitsu, S. (1986). Influence of soil temperature on the growth of fruit vegetable grafted on different stocks. Bulletin of Vegetable and Ornamental Crops Research Station Japan. 9: 43-58.

Onduso, J. N. 2014. Management of bacterial wilt of tomato by use of resistant rootstock. Masters of science Thesis. University of Nairobi, Kenya.

Otani, T. and Seike, N. 2007. Rootstock control of fruit dieldrin concentration in grafted cucumber (Cucumis sativus). Journal of Pesticide Science. 32(3):235242. 
Palada, M.C. and Wu, D.L. 2008. Evaluation of chili rootstocks for grafted sweet pepper production during the hot-wet and hot-dry seasons in Taiwan. Acta Horticulturae.767:167-174.

Pandey, A.K. and Rai, M. 2003. Prospects of grafting in vegetables: an appraisal. Vegetable science. 30(2): 101-109.

Paplomatas, E.J., Elena, K., Tsagkarakou, A. and Perdikaris, A.2002. Control of Verticillium wilt of tomato and cucurbits through grafting of commercial varieties on resistant rootstocks. Acta Horticulturae. 579:445-449.

Penella, C., Nebauer, S.G., López-Galarza, S., Bautista, A.S., Burruezo, A. R., Calatayud, A. 2014. Evaluation of some pepper genotypes as rootstocks in water stress conditions. Horticultural Science (Prague). 41(4): 192-200.

Petran, A.J. 2013. Interspecific grafting of tomato (Solanum lycopersicum) onto wild eggplant (Solanum torvum) for increase environmental tolerances. Msc. Thesis, University of Minnesota, Minneapolis, USA. http://umn.edu.

Poffley, M. 2003. Grafting tomatoes for bacterial wilt control. Agnote, 603, No. B40.

Pogonyi, A., Pek, Z., Helyes, L. and Lugasi, A. 2005. Effect of grafting on the tomato's yield,quality and main fruit components in spring forcing. Acta Alimentaria. 34:453-462.

Proebsting, W.M.P., Hedden, M.J., Lewis, S.J. and Croker- Proebsting, L.N. 1992. Gibberellin concentration and transport in genetic lines of pea. Plant Physiology, 100: 1354-1360.

Rahman, M.A., Rashid, M.A., Salam, M.A., Masud, M.A.T., Masum, A.S.M.H., and Hossain, M.M. 2002. Performance of some grafted eggplant genotypes on wild Solanum root stocks against root- knot nematode. Journal of Biological Sciences 2:446-448.

Raskin, I., Smith, R.D. and Salt, D.E., 1997. Phytoremediation of metals: using plants to remove pollutants from the environment. Current Opinion in Biotechnology. 8: 221-226.

Rivard, C. L., O'Connell, S., Peet, M. M., and Louws, F. J. 2010. Grafting Tomato with Interspecific Rootstock to Manage Diseases Caused by Sclerotium rolfsii and Southern Root-Knot Nematode. Plant Disease. 94(8): 10151021.

Rivard, C. L., O'Connell, S., Peet, M. M., Welker, R. M. and Louws, F. J. 2012. Grafting tomato to manage bacterial wilt by Ralstonia solanacearum in the Southeastern United States. Plant disease .96(7):973-978.

Rivard, C.S. and F.J. Louws. 2008. Grafting to Manage Soilborne Disease in Heirloom Tomato Production. HortScience. 43(7): 2104-2111.

Rivero, R. M., Ruiz, J. M. and Romero, L. 2003a. Role of grafting in horticultural plants grown under stress conditions. Journal of Food, Agriculture, \& Environment. 1:70-74.

Rivero, R.M., Ruiz, J.M., and Romero, L. 2004. Iron metabolism in tomato and watermelon plants: influence of grafting. Journal of Plant Nutrition. 27:2221-2234.

Rivero, R.M., Ruiz, J.M., Sanchez, E., Romero, L.2003b. Does grafting provide resistance to tomato rootstocks against root-knot nematode? Journal of Bio-Science. 2:446-448.

Sanchez-Rodriguez, E., Ruiz, J. M., Ferreres, F. and Moreno, D.A. 2012. Phenolic Metabolism in Grafted versus Nongrafted Cherry Tomatoes under the Influence of Water Stress. Journal of Agricultural and Food Chemistry. 59(16):8839-8846. 
Santa-Cruz, A., Martinez-Rodriguez, M.M., Perez-Alfocea, F., Romero-Aranda,.R., and. Bolarin, M.C. 2002. The rootstock effect on the tomato salinity response depends on the shoot genotype. Plant Science. 162(5):825-831.

Satisha, J., Prakash, G.S., Bhatt, R.M. and Kumar, P. 2007. Physiological mechanisms of water use efficiency in grape rootstocks under drought conditions. International Journal of Agricultural Research . 2: 159-164.

Sato, N. and Takamatsu, T. 1930. Grafting culture of watermelon. Nogyo sekai. 25: 24-28 [in Japanese].

Schwarz, D., Rouphael, Y., Colla, G. and Venema J.H. 2010. Grafting as a tool to improve tolerance of vegetables to abiotic stresses: Thermal stress, water stress and organic pollutants. Scientia Horticulturae.127(2):162-171.

Tateishi, K. 1927. Grafting watermelon on squash. Journal of the Japanese Society for Horticultural Science. 39:5-8.

Traka-Mavrona, E., Koutsika-Sotiriou, M, and Pritsa, T. 2000. Response of squash (Cucurbita spp.) as rootstock for melon (Cucumis melo L.). Scientia Horticulturae. 83: 353-362.

Tsouvaltzis, P.I., Siomos, A.S. and Dogras, K.C. 2004. The effect of the two tomatoes grafting on the performance, earliness and fruit quality. In: Proceedings of 21st Pan-Hellenic Congress of the Greek Society for Horticultural Science, Ioannina, Greece, 8-10 October 2003. vol. 11, Pp. 51-55.

Venema, J., Linger, P., Heusden, A.W., Hasselt, P.R. and Brüggemann, W.
2005. The inheritance of chilling tolerance in tomato (Lycopersicon spp.). Plant Biology. 7(2): 118-130.

Venema, J.H., Dijk, B.E., Bax, J.M., Van Hasselt, P.R., and Elzenga, J.T.M. 2008. Grafting tomato (Solanum lycopersicum) onto the rootstock of a high-altitude accession of Solanum habrochaites improves suboptimaltemperature tolerance. Environmental and Experimental Botany. 63(1): 359-367.

Vitale, A., Rocco, M., Arena, S., Giuffrida, F., Cassaniti, C., Scaloni, A., Lomaglio, T., Guarnaccia, V., Polizzi, G., Marra, M. and Leonardi, C. 2014. Tomato susceptibility to fusarium crown and root rot: effect of grafting combination and proteomic analysis of tolerance expression in the rootstock. Plant Physiology and Biochemistry. 83:207216.

Wang, S., Yang, R., Cheng, J., and Zhao, J. 2007. Effect of rootstocks on the tolerance to high temperature of eggplants under solar greenhouse during summer season. Acta Horticulturae. 761: 357-360.

Yu, H.Y., Li, T.X., Zhou, J.M., 2005. Second salinization of greenhouse soil and its effects on soil properties. Soils. 37: 581-586. (in Chinese with English abstract).

Zijlstra, S. and Nijs, A.P.M. 1987. Effects of root systems of tomato genotypes on growth and earliness, studied in grafting experiments at low temperature. Euphytica, 36(2): 693-700.

\section{How to cite this article:}

Aradhana Sen, Ranjit Chatterjee, Pranali Bhaisare and Sushmita Subba. 2018. Grafting as an Alternate Tool for Biotic and Abiotic Tolerance with Improved Growth and Production of Solanaceous Vegetables: Challenges and Scopes in India. Int.J.Curr.Microbiol.App.Sci. 7(01): 121-135. doi: https://doi.org/10.20546/ijcmas.2018.701.014 